\title{
SOURCES OF POULTRY MEAT CONTAMINATION WITH THERMOPHILIC CAMPYLOBACTER BEFORE SLAUGHTER
}

\author{
Paulo Rogério Franchin ${ }^{1}$; Kofi E. Aidoo²; Cleide Rosana Vieira Batista ${ }^{1 *}$ \\ ${ }^{1}$ Departamento de Ciência e Tecnologia de Alimentos, Centro de Ciências Agrárias, Universidade Federal de Santa Catarina, \\ Florianópolis, SC, Brasil. ${ }^{2}$ School of Biological and Biomedical Sciences, Glasgow Caledonian University, Glasgow, UK.
}

Submitted: March 25, 2004; Returned to authors for corrections: August 12, 2004; Approved: April 28, 2005

\begin{abstract}
The possible sources of Campylobacter spp. in poultry meat before slaughter were studied by examining samples of feathers, cloaca swabs, litter swabs, transport coops, rinse water from coop washing equipment, and chicken breast supports in the slaughter line just before stunning. The samples were collected from 8 broiler houses and from 8 different producers, from a poultry integration system in southern Brazil. The study was carried out over a 12-month period, and each broiler house was sampled in three consecutive flocks, for a total of 24 flocks/broiler house. Campylobacter was found in $79.2 \%$ of the feather samples, followed by cloacal swabs (75.0\%) and transport coop (50.0\%), litter (37.5\%), breast support (33.3\%) and coop rinse water (25.0\%) samples. Considering the combined results of cloacal, feather and litter samples, 21 (87.5\%) of the 24 chicken batches contained thermophilic Campylobacter in at least one of these samples prior to slaughter. Thermophilic Campylobacter were found in 22 of 24 chicken batches destined to slaughter, corresponding to $91.7 \%$ contaminated batches.
\end{abstract}

Key words: Campylobacter, poultry processing

\section{INTRODUCTION}

In the last 25 years, reports of cases of human illness caused by Campylobacter spp. have increased year by year. Most Campylobacter spp. are not identified at the species level, but when this is done, $C$. jejuni is always the predominant species, followed by $C$. coli and, rarely, $C$. lari. Although $C$. jejuni is an intestinal saprophyte of poultry, it is one of the most commonly isolated gastrointestinal pathogens in humans, and poultry meat is the principal vehicle $(2,8)$. In the United States, human infections with Campylobacter are estimated to rang affect 2.1 to 2.4 million people per year and are mainly related to contaminated poultry meat $(12,20)$. However, other animals such as cattle, sheep and pigs are also known to be carriers of Campylobacter spp. In the United Kingdom, an 18-month study showed the presence of Campylobacter in heat- processed cow's milk (24).
Campylobacter has been isolated from poultry in several countries. Uyttendaele et al. (21) studied the occurrence of food-borne pathogens in poultry carcasses and poultry products for sale on Belgium markets imported from countries of the European Union (EU) and found Campylobacter spp. in $21.9 \%$ of 247 Belgian samples, $30.2 \%$ of 427 French samples, $15.4 \%$ of 13 Italian samples, and $54.5 \%$ of 44 United Kingdom samples. The authors further reported that over $25 \%$ of the Campylobacter isolates were either $C$. jejuni or $C$. coli. There is very little published information on the occurrence of Campylobacter spp. in Brazilian poultry products. One study carried out on retail chicken in the State of Sao Paulo between 1986 (1) and 1987 (9) showed Campylobacter spp. in 47.5 and $62.2 \%$ of samples, respectively, demonstrating an increase of $31 \%$ in one year.

The sources of Campylobacter spp. in retail poultry are still unclear. Broilers, analyzed in the present study, are reared in

*Corresponding Author. Mailing address: Departamento de Ciência e Tecnologia de Alimentos, Centro de Ciências Agrárias, Universidade Federal de Santa Catarina, Rodovia Ademar Gonzaga, 1346, Itacorubi. 88034-001, Florianópolis, SC, Brasil. Tel.: (+5548) 331-5380/5379, Fax: (+5548) 331-9943. E-mail: cbatista@mbox1.ufsc.br 
modern, open-air houses, with plastic curtains, slatted floors and automatic feeders and drinkers. On reaching slaughter age, the animals are placed in plastic coops in piles and transported to the slaughterhouse. The chickens are unloaded from the coop, and shackled and slaughtered on a modern automated processing line of 9000 birds per hour.

Although chickens may excrete $10^{4}$ to $10^{8}$ Campylobacter cells per gram of feces, they are asymptomatic (16). It is believed that the source of bacterial contamination of poultry meat is essentially the intestine or gut content which may come in contact with carcasses already in the broiler house, and during transport and slaughter, either directly or indirectly, through a vehicle such as transport and processing equipment. High levels of bacterial cross-contamination may occur especially during defeathering and water chilling, with intestinal contamination apparently being the only source. However, these levels may also increase during evisceration of the carcasses, washing and processing due to contamination by personnel $(14,23)$.

Although Campylobacter has been isolated from different body parts of the chicken such as cloaca $(4,11)$, carcasses, feathers and crops (13), there is little information about the possible sources of contamination. This information is extremely important in order to adopt proper control measures and thus to reduce carcass contamination. In the UK, stringent control measures introduced in recent years have been successful in reducing contamination with Salmonella but not with Campylobacter and the levels of this microorganism remain high. Apparently, Campylobacter is not sensitive to control measures that reduce Salmonella contamination.

In the UK, Campylobacter continues to be a great challenge and, therefore, the government prioritizes the fight against this pathogen in order to reduce food-borne diseases caused by this microorganism (FSA, 2003).

In 2001, the Brazilian poultry industry was responsible for $11.4 \%$ of the world production of $58,987,000$ tons (15). The high incidence of Campylobacter spp. in chicken products worldwide has encouraged the present study. The aim of this investigation was to identify the sources of Campylobacter spp. in poultry slaughterhouses by analyzing transport coops, rinse water from coops, breast support lines, cloaca, feathers and litter swabs. The results of this study should be helpful in the identification of the critical points that need to be controlled in order to reduce the incidence of Campylobacter contamination in the poultry industry.

\section{MATERIALS AND METHODS}

\section{Litter samples}

Three litter samples each were randomly collected from 8 different chicken producers, for a total of 24 samples, and analyzed for the presence of Campylobacter spp. Samples were collected in 2002 and 2003 and each flock was considered a chicken batch. The average age of the flocks was 32 to 34 days and flock size was about 18,000 birds. Samples were collected from each batch when the chickens were 18 to 24 days old.

Swab samples were taken from the litter by moistening each swab (BioPro Sample Bags, International BioProducts, Inc., Bothell, WA) with $10 \mathrm{~mL}$ sterile buffered peptone water (BPW) (Merck, Art.107228-0). Samples were taken by swabbing the litter back and forth in parallel movements towards to the water-supply pipes on the left and the right side of the poultry house. The swabs were transported to the laboratory in isothermic boxes and tested on the same day. The swabs were placed in flasks containing $100 \mathrm{~mL}$ BPW and shaken for 1 minute using a mixer (Model MA 440 Marconi, Piracicaba, São Paulo, Brazil). After homogenization, a 10-mL sample was transferred to $90 \mathrm{~mL}$ of Bolton broth (Oxoid, BB CM 983, Basingstoke, Hampshire, UK) containing selective supplement (Oxoid, SR 208E) in a sterile glass flask system developed by Franchin (Fig 1). The flasks were incubated under microaerobic conditions $\left(5 \% \mathrm{O}_{2}, 10 \% \mathrm{CO}_{2}\right.$ and $\left.85 \% \mathrm{~N}_{2}\right)$ initially at $37^{\circ} \mathrm{C}$ for 4 $\mathrm{h}$ and then at $42^{\circ} \mathrm{C}$ for $44 \mathrm{~h}$. The sample was then plated onto modified Bolton agar (MBA) and modified charcoal cefoperazone desoxycholate agar (mCCDA) for isolation and enumeration of Campylobacter spp.

The MBA culture medium described by Line (10) was modified by supplementation of Bolton broth (Oxoid, CM 983) with $1.5 \%$ agar-agar, $0.5 \mathrm{~g} / \mathrm{L}$ ferrous sulphate (Carlo Erba, Code

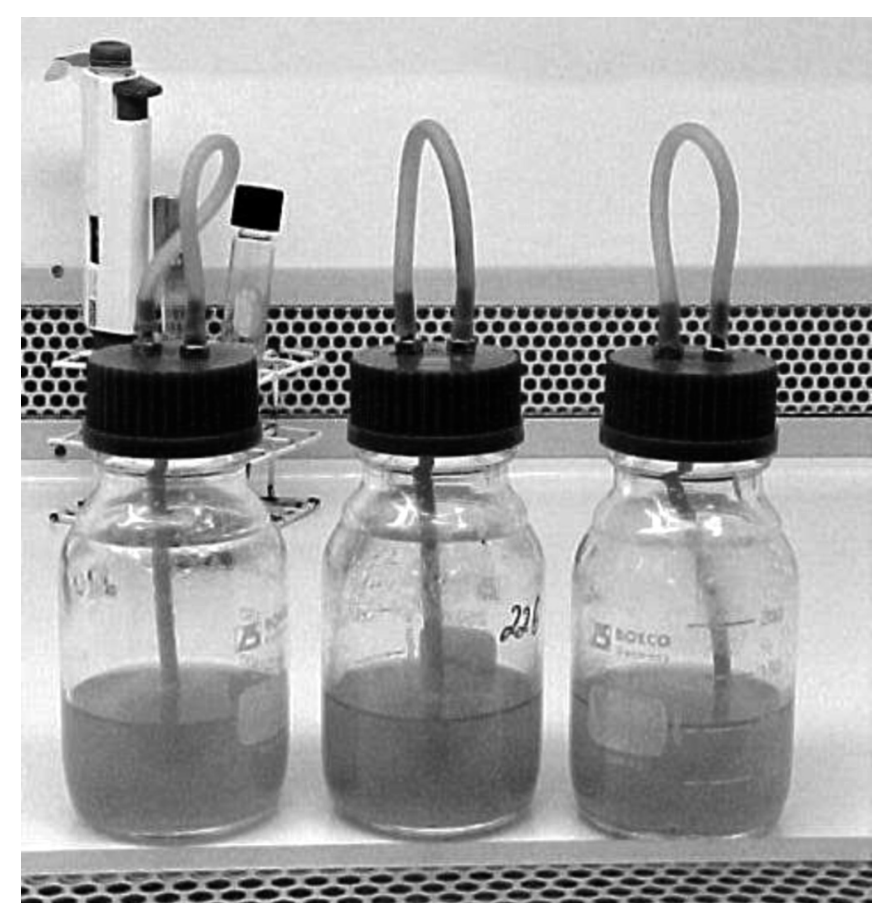

Figure 1. Modified microaerobic incubation flasks. 
451454) and 200 ppm of 2,3,5-triphenyltetrazolium chloride solution (TTC) (Merck, Art. 108380). Thereafter, a selective supplement (Oxoid, SR 183E) containing $20 \mathrm{mg} / \mathrm{L}$ cefoperazone, $20 \mathrm{mg} / \mathrm{L}$ trimethoprim, $20 \mathrm{mg} / \mathrm{L}$ vancomycin and $50 \mathrm{mg} / \mathrm{L}$ cycloheximide was added.

Selective supplement (Oxoid, SR 155E) containing $32 \mathrm{mg} / \mathrm{L}$ ceforazone and $10 \mathrm{mg} / \mathrm{L}$ amphotericin $\mathrm{B}$ was added to mCCDA medium (Oxoid, CM 739) and used as a blood-free selective medium for the isolation of $C$. jejuni, $C$. coli and $C$. lari. The MBA and mCCDA plates were incubated in a microaerobic system at $42^{\circ} \mathrm{C}$ for 24 to $48 \mathrm{~h}$. The isolated colonies were identified using the following tests: catalase, oxidase, morphology and motility under a phase contrast microscope, latex agglutination (Oxoid, Dryspot Campylobacter Test DR 150M), and API Campy (BioMérieux, France).

\section{Chicken transport coop samples}

Swab samples were collected at the processing plant from the internal and external surface areas of two transport coops for each batch of chickens. Two swabs were taken from each coop, for a total 4 swabs per batch. After sampling, the swabs were placed in 50-mL sterile tubes containing $20 \mathrm{~mL}$ BPW. The tubes were shaken in a shaker (Phoenix, Model AP 56, Brazil) for 30 seconds. Thereafter, $1 \mathrm{~mL}$ of the homogenized samples was transferred to sterile tubes containing $9 \mathrm{~mL}$ Bolton broth and incubated under microaerobic conditions at $37^{\circ} \mathrm{C}$ for $4 \mathrm{~h}$, and then at $42^{\circ} \mathrm{C}$ for an additional $44 \mathrm{~h}$. The cultures were then transferred to solid media as described for the litter samples. The isolated colonies were identified as described previously.

\section{Coop rinse water samples}

Rinse water $(50 \mathrm{~mL})$ samples from the coops were collected directly from the rinse machine. One $\mathrm{mL}$ of each water sample was added to tubes containing $9 \mathrm{~mL}$ Bolton broth and incubated at $37^{\circ} \mathrm{C}$ for $4 \mathrm{~h}$ and then at $42^{\circ} \mathrm{C}$ for $44 \mathrm{~h}$. The cultures were transferred to solid media as described for the litter samples. The isolated colonies were identified as described previously.

\section{Feather samples}

Before starting the slaughtering process, 10 coops were separated from each batch, and feather samples were removed from one chicken in each coop, for a total of 10 chickens per sample (approximately $4 \mathrm{~g}$ of feathers). The feathers were taken by hand from the neck and the breast using sterile gloves. The feather samples were placed in sterile bags (WHIRL-PACK, Millipore Ind. Com. Ltd, Billerica, Massachusetts, USA), 100 $\mathrm{mL} \mathrm{BPW}$ was added and the bags were shaken for 30 seconds. Five $\mathrm{mL}$ of the liquid was transferred to tubes containing $45 \mathrm{~mL}$ Bolton broth and incubated under microaerobic conditions at $37^{\circ} \mathrm{C}$ for $4 \mathrm{~h}$ and then at $42^{\circ} \mathrm{C}$ for an additional $44 \mathrm{~h}$. The cultures were transferred to solid media and identified as described for the other litter samples.

\section{Cloacal samples}

Before starting the slaughtering process, 10 coops were separated from each batch, and cloacal samples were obtained from one chicken in each coop, for a total of 10 chickens per sample. The cloacal samples were collected using the same swab for two chickens. The five swabs were placed in sterile flasks to which $20 \mathrm{~mL}$ BPW was added. The flasks were shaken for 30 seconds and $2 \mathrm{~mL}$ of the liquid was transferred to sterile flasks containing $18 \mathrm{~mL}$ Bolton broth. The cultures were incubated, subcultured and identified as described for the other litter samples.

\section{Breast support samples}

The breast support is designed to calm the chicken after hanging and also to protect the breast area. Two swabs were taken from a $100-\mathrm{cm}^{2}$ surface area of the breast support line before the stunning bath. The swabs were placed in tubes with $10 \mathrm{~mL} \mathrm{BPW}$. After shaking the sample for 15 seconds, $1 \mathrm{~mL}$ of the liquid was transferred to sterile flasks containing $9 \mathrm{~mL}$ Bolton broth, incubated, subcultured and identified as described for the other litter samples.

\section{Statistics analysis}

The nonparametric McNemar test (17) was used for comparison of the results. Values of $\mathrm{X}^{2}>3.84$ were considered to be significant at 0.05 level.

\section{RESULTS AND DISCUSSION}

Thermophilic Campylobacter were detected in 22 of 24 chicken batch samples destined to slaughter, corresponding to a $91.7 \%$ rate of contaminated batches.

Table 1 shows the incidence of thermophilic Campylobacter in samples collected before the bleeding process. There was a high incidence of Campylobacter in the feather samples (79.2\%), followed by cloacal $(75.0 \%)$, chicken transport coop $(50.0 \%)$, litter swab (37.5\%), breast support (33.3\%) and coop rinse water (25.0\%) samples. Table 2 shows the presence of Campylobacter in the different samples collected from three different batches of 8 producers.

The occurrence of thermophilic Campylobacter showed $\mathrm{X}^{2}$ $=4.92(\mathrm{p}=0.0265)$ for combined results for cloaca and litter samples and $\mathrm{X}^{2}=5.78(\mathrm{p}=0.0162)$ for feather and litter samples. These results indicate a significant difference between samples. On the other hand, the combined results for feather and cloacal samples showed no significant difference $\left(X^{2}=0.000, p<0.0001\right)$. These results indicate that feathers as well as cloaca are more important as a source of chicken contamination than the litter samples.

According to the results obtained for cloacal, feather and litter samples, $21(87.5 \%)$ of the 24 chicken batches to be slaughtered contained thermophilic Campylobacter in at least 
Table 1. Occurrence of thermophilic Campylobacter spp. in chicken samples collected at different points before slaughter.

\begin{tabular}{|c|c|c|c|c|}
\hline $\begin{array}{l}\text { Sampling } \\
\text { points } \\
\text { examined }\end{array}$ & $\begin{array}{c}\text { Number of } \\
\text { samples } \\
\text { samples }\end{array}$ & $\begin{array}{l}\text { Number of } \\
\text { positive }\end{array}$ & $\begin{array}{l}\text { Isolated } \\
\text { species }\end{array}$ & $\begin{array}{c}\text { Positivity } \\
(\%)\end{array}$ \\
\hline Litter & 24 & 9 & $\begin{array}{l}\text { C. jejuni doylei (6) } \\
\text { C. upsaliensis (3) }\end{array}$ & 37.5 \\
\hline Transport coop & 24 & 12 & $\begin{array}{l}\text { C. jejuni doylei (8) } \\
\text { C. coli (3) } \\
\text { C. jejuni jejuni } 1 \text { (1) }\end{array}$ & 50.0 \\
\hline Coop rinse water & 24 & 6 & $\begin{array}{l}\text { C. jejuni doylei (4) } \\
\text { C. jejuni jejuni } 1 \text { (1) } \\
\text { C. coli }(1)\end{array}$ & 25.0 \\
\hline Cloaca & 24 & 18 & $\begin{array}{l}\text { C. jejuni jejuni } 1(9) \\
\text { C. jejuni doylei (6) } \\
\text { C. coli (3) }\end{array}$ & 75.0 \\
\hline Feather & 24 & 19 & $\begin{array}{l}\text { C. jejuni doylei }(7) \\
\text { C. jejuni jejuni } 1(10) \\
\text { C. coli (2) }\end{array}$ & 79.2 \\
\hline Breast support & 24 & 8 & $\begin{array}{l}\text { C. jejuni doylei (4) } \\
\text { C. jejuni jejuni } 1 \text { ( } 3 \text { ) }\end{array}$ & 33.3 \\
\hline Total & 144 & 72 & & 50.0 \\
\hline
\end{tabular}

scalding, from the plucking equipment. Kotula and Pandya (7) reported $7.5 \log _{10}$ CFU of Campylobacter/g in feathers removed from the breast of the chicken, and Berrang et al. (3) found $5.4 \log 10 \mathrm{CFU} / \mathrm{g}$ in the feathers and $3.8 \log 10 \mathrm{CFU} / \mathrm{g}$ in the skin of 18 chicken samples examined at the end of the bleeding tunnel, but before scalding. The latter authors also found the crop samples to be $100 \%$ positive for Campylobacter spp.

The present study showed a low incidence of thermophilic Campylobacter spp. in the litter swabs compared to cloacal and feather samples, which might be due to environmental conditions such oxygen, relative humidity and temperature reported to affect the survival of Campylobacter spp. $(2,22)$.

Of the 22 chicken batches positive for thermophilic Campylobacter, only one batch (No. 10) showed the absence of the microorganism in litter, cloacal and feather samples. The organism was present in the transport coop and on the breast support equipment, indicating that these areas could be possible sources of cross- contamination.

Thermophilic Campylobacter were detected in $50 \%$ of the coop samples after one of these samples. These results are similar to those reported by Stern et al. (19) in 1998, in the US, who showed the presence of Campylobacter in 28 of 32 chicken batches (87.5\%).

In the present study, Campylobacter spp. were isolated from $75 \%$ of cloacal samples, a rate higher than that reported by Machado (11) and Carvalho (4) who detected Campylobacter spp. in about $57 \%$ and $42 \%$ of samples, respectively. Machado (11) used 30 individual chickens as the sample unit, whereas Carvalho (4) used 5 chickens to form one pool of cloacal swabs and analyzed 50 pooled samples; in the present study each pool consisted of 10 cloacal samples and 24 pooled samples were analyzed.

In Denmark, Nielsen et al. (13) examined 929 cloacal swabs between 1995 and 1996 and found that 36\% $t$ were positive for thermophilic Campylobacter. In their study the authors did not use the broth enrichment step but rather plated directly onto CCDA agar plus selective supplement. In Holland, JacobsReitsma (6) found $67 \%$ of 43 flocks to be positive for Campylobacter spp., with each flock being sampled by taking fresh cecal droppings of 30 individual birds. The swabs were also directly streaked onto Campylobacter blood-free selective medium, without the enrichment step.

At the defeathering stage, $79.2 \%$ of the samples were positive for thermophilic Campylobacter, which is more than twice the level reported by Carvalho (38\%) who collected feathers, after transportation. De Zutter (5) studied 12 chicken batches of broiler flocks and the possibility of cross-contamination during transit to slaughter, and found that two batches which were initially free of Campylobacter spp. became infected with the organism when they reached the slaughter stage, indicating that infection occurred during transportation. The same author (5) examined 72 trucks used to transport the 12 batches and observed that $75 \%$ were positive for Campylobacter before cleaning and disinfection and $83 \%$ were positive after cleaning and disinfection, indicating that the coop cleaning procedure was inadequate and may have resulted in the spreading of the organism. Stern et al. $(18,19)$ found that transport coops arriving from the farms to the processing plant were sometimes contaminated with Campylobacter spp. before being used to transport the flocks under study. In the same study regarding the occurrence of Campylobacter spp. in coops before and after transportation of flocks from 4 producers, the levels of the microorganism increased from 64.7 to $89.4 \%$ in the coops used to transport flocks.

In the present study, $25 \%$ of coop rinse water samples were also positive for thermophilic Campylobacter. This water could be a source of cross-contamination for news flocks that will be transported in these coops cleaned with this contaminated water.

Although breast support samples showed relatively low levels of thermophilic Campylobacter, their role in the 
Table 2. Occurrence of thermophilic Campylobacter spp. in chicken samples collected from 8 chicken producers at different points before slaughter.

\begin{tabular}{|c|c|c|c|c|c|c|c|}
\hline \multirow[b]{2}{*}{ Producer } & \multirow[b]{2}{*}{ Batch } & \multicolumn{6}{|c|}{ Thermophilic Campylobacter } \\
\hline & & Litter & $\begin{array}{c}\text { Transport } \\
\text { coop }\end{array}$ & $\begin{array}{l}\text { Coop } \\
\text { rinse } \\
\text { water }\end{array}$ & Cloaca & Feather & $\begin{array}{l}\text { Breast } \\
\text { support }\end{array}$ \\
\hline \multirow{3}{*}{ A } & 1 & - & - & - & - & + & - \\
\hline & 2 & - & - & - & + & + & + \\
\hline & 3 & - & + & + & + & + & + \\
\hline \multirow{3}{*}{ B } & 4 & + & - & - & + & + & + \\
\hline & 5 & + & + & - & + & + & + \\
\hline & 6 & - & + & + & + & + & + \\
\hline \multirow{3}{*}{$\mathrm{C}$} & 7 & - & - & - & + & + & + \\
\hline & 8 & + & + & - & - & + & - \\
\hline & 9 & - & - & - & + & + & - \\
\hline \multirow{3}{*}{ D } & 10 & - & + & - & - & - & + \\
\hline & 11 & - & + & - & + & + & - \\
\hline & 12 & - & - & - & + & + & - \\
\hline \multirow{3}{*}{$\mathrm{E}$} & 13 & - & - & - & - & - & - \\
\hline & 14 & - & - & - & + & + & + \\
\hline & 15 & - & - & - & - & - & - \\
\hline \multirow{3}{*}{$\mathrm{F}$} & 16 & + & + & + & + & + & - \\
\hline & 17 & + & - & - & + & + & - \\
\hline & 18 & + & + & + & + & + & - \\
\hline \multirow{3}{*}{$\mathrm{G}$} & 19 & + & + & + & + & - & - \\
\hline & 20 & + & + & - & + & + & - \\
\hline & 21 & - & - & - & + & + & - \\
\hline \multirow{3}{*}{$\mathrm{H}$} & 22 & - & + & + & + & + & - \\
\hline & 23 & + & + & - & - & - & - \\
\hline & 24 & - & - & - & + & + & - \\
\hline \multicolumn{2}{|c|}{$\begin{array}{l}\text { Number of } \\
\text { positive samples }\end{array}$} & 9 & 12 & 6 & 18 & 19 & 8 \\
\hline
\end{tabular}

(+) presence of Campylobacter spp.; (-) absence of Campylobacter spp.

transmission of the microorganism is important since this piece of equipment is normally in direct contact with the breast area of the chicken.

The high incidence of thermophilic Campylobacter (75\%) in cloacal samples suggests that the presence of the microorganism in poultry is mainly due to intestinal contamination, as also reported by other authors $(14,23)$. Although 25\% of the chicken batches did not show thermophilic Campylobacter in the cloaca, their presence in the litter, coops, feathers and breast support renders the chicken meat vulnerable to cross-contamination, thus increasing the risk of the presence of this pathogen in chicken meat and products. The present study showed that chicken feathers and feces are responsible for coop contamination instead of the coops contaminating the chicken feathers.

In conclusion, thermophilic Campylobacter spp. were found in $91.7 \%$ of the chicken batches collected at different points prior to slaughter. The major points or sources of contamination with thermophilic Campylobacter were cloaca and feathers. However, in the risk assessment of the poultry industry, the coops as well as breast supports should be considered as critical points which may contribute to cross- contamination.

\section{RESUMO}

\section{Fontes de contaminação da carne de frango com Campylobacter termofílico antes do abate}

As possíveis fontes de contaminação com Campylobacter termofílicos em carne de frango, antes do abate, foram estudadas através da análise de amostras de penas, cloaca, cama de aviário, gaiolas de transporte, água de lavagem da máquina de lavar gaiola e o suporte para peito de frango na linha de abate, imediatamente antes do atordoamento. As amostras foram coletadas em 8 aviários de 8 produtores diferentes, da região Sul do Brasil. O estudo foi realizado durante o período de um ano, onde cada aviário foi amostrado três vezes, perfazendo um total de 24 coletas nos aviários.Campylobacter foi encontrado em 79,2\% das amostras de penas, seguido por cloaca $(75,0 \%)$, gaiola de transporte $(50,0 \%)$, cama de aviário $(37,5 \%)$, suporte para peito $(33,3 \%)$ e água de lavagem de gaiola $(25,0 \%)$. Considerando-se a combinação dos resultados encontrados entre amostras de cloaca, penas e cama de aviário, 21 (87,5\%) dos 24 lotes de frango a serem abatidos apresentaram Campylobacter termofílico pelo menos em uma dessas amostras. Campylobacter termofílico foi encontrado em 22 dos 24 lotes de aves destinados ao abate, o que significa $91,7 \%$ dos lotes contaminados.

Palavras-chave: Campylobacter, processamento de frango

\section{REFERENCES}

1. Almeida, P.F.; Serrano, A.M. Ocorrência de Campylobacter fetus subspécie jejuni em carcaças de frango e suínos. Rev. Microbiol. 18(3), 279-283, 1987.

2. Aquino, M.H.C.; Franco, R.M.; Tibana, A. Campylobacter jejuni na avicultura: importância e métodos de controle. Hig. Alim., 9(36), 17-19, 1995.

3. Berrang, M.E.; Buhr, R.J.; Cason, J.A. Campylobacter recovery from external and internal organs of commercial broiler carcass prior to scalding. Poult. Sci., 79, 286-290, 2000. 
4. Carvalho, A.C.F.B.; Lima, V.H.C.; Pereira, G.T. Determinação dos principais pontos de contaminação de frangos por Campylobacter durante o abate industrial. Hig. Alim., 16(99), 89-93, 2000.

5. De Zutter, L. Crates inoculate broilers with Salmonella and Campylobacter. World Poult., 16(4), 19, 2000.

6. Jacobs-Reitsma, W.F. Campylobacter bacteria in breeder flocks. Avian Dis. 39 (11), 355-359, 1995.

7. Kotula, K.L.; Pandya, Y. Bacterial contamination of broiler chickens before scalding. J. Food Prot., 58(12), 1326-1329, 1995.

8. Kramer, J.M.; Frost, J.A.; Bolton, F.J.; Wareing, D.R.A. Campylobacter contamination of raw meat and poultry at retail sale: Identification of multiple types and comparison with isolates from human infection. J. Food Prot., 63(12), 1654-1659, 2000.

9. Leitão, M.F.F.; Taniwaki, M.H.; Uboldi-Eiroa, M.N. Campylobacter jejuni e $C$. coli no trato intestinal e superfície de carcaças de frango recém abatidos. Col. ITAL, 16, 37-47, 1986.

10. Line, J.E. Development of a selective differential agar for isolation and enumeration of Campylobacter spp. J. Food Prot., 64(11), 1711-1715, 2001.

11. Machado, R.A.; Tosin, I.; Leitão, M.F.F. Occurrence of Salmonella sp. and Campylobacter sp. in chickens during industrial processing. Rev. Microbiol., 25(4), 239-244, 1994.

12. Mead, P.S. Food-related illness and death in the United States. Emerg. Infect. Dis., 5: 607-625, 1999.

13. Nielsen, E.M.; Engberg, J.; Madsen, M. Distribution of serotypes of Campylobacter jejuni and C. coli from Danish patients, poultry, cattle and swine. FEMS Immunol. Med. Microbiol., 19, 47-56, 1997.

14. Oosterom, J.; Notermans, S.; Karman, H.; Engels, G.B. Origin and prevalence of Campylobacter jejuni in poultry processing. J. Food Prot., 46(4), 339-344, 1983.

15. ASSOCIAÇÃO BRASILEIRA DE EXPORTADORES DE FRANGOS. Relatório Anual: 2001. São Paulo, 2001.
16. Schoeni, J.L; Doyle, M.P. Reduction of Campylobacter jejuni colonization of chicks by cecum colonizing bacteria producing anti $C$. jejuni metabolites. Appl. Environ. Microbiol., 58(2), 664-670, 1992.

17. Siegel, S. Nonparametric Statistics for the Behavioral Sciences. New York: McGraw- Hill, 1956, 350p.

18. Stern, N.J.; Clavero, M.R.S.; Bailey, J.S.; Cox, N.A.; Robach, M.C. Campylobacter spp in broiler on the farm and after transport. Poult. Sci., 74, 937-941, 1995.

19. Stern, N.J.; Fedorka-Cray, P.; Bailey, J.S.; Cox, N.A.; Craven, E.; Hiett, K.L.; Musgrove, M.T.; Ladely, S.; Cosby, D. Mead, G.C. Distribution of Campylobacter spp. in selected U.S. poultry production and processing operations. J. Food Prot., 64(11), 17051710,2001

20. Tauxe, R.V. Epidemiology of Campylobacter jejuni infections in the United States and other industrial nations. In: Nachamkin, I.; Blaser, M.J.; Tompkins, L.S. Campylobacter jejuni: current and future trends. Washington: American Society for Microbiology, 1992, p.9-12.

21. Uyttendaele, M.; De Troy, P.; Debevere, J. Incidence of Salmonella, Campylobacter jejuni, Campylobacter coli and Listeria monocytogenes in poultry carcasses and different types of poultry products for sale on the Belgian retail market. J. Food Prot., 62(7), 735-740, 1999 .

22. Varnam, A.H.; Evans, M.G. Foodborne pathogens: an illustrated text. London: Manson Publishing, 1996, 557p.

23. Wempe, J.M.; Genigeorgis, C.A.; Farver, T.B.; Yusufu, H.I. Prevalence of Campylobacter jejuni in two California chicken processing plants. Appl. Environ. Microbiol., 45(2), 355-359,1989.

24. ZOONOSES Report, UK 2000, Department for Environment, Food and Rural Affairs, 7-9, 2002

25. FSA: FOOD STANDARDS AGENCY. Research and Survey Programmes. Annual Report 2003. FSA publications. London, UK, 2003. 